\title{
Time-Course of Tissue Factor Plasma Level in Patients with Acute Coronary Syndrome
}

\author{
J. BIS ${ }^{1}$, J. VOJÁČEK ${ }^{1}$, J. DUŠEK ${ }^{1}$, M. PECKA ${ }^{2}$, V. PALIČKA ${ }^{3}$, J. ŠŤÁSEK ${ }^{1}$, J. MALÝ $^{2}$ \\ ${ }^{1}$ First Department of Medicine, ${ }^{2}$ Second Department of Medicine, ${ }^{3}$ Institute of Clinical \\ Biochemistry and Diagnostics, Charles University Prague, Medical Faculty in Hradec Králové and \\ University Hospital Hradec Králové, Czech Republic
}

Received February 4, 2008

Accepted July 22, 2008

On-line November 4, 2008

\begin{abstract}
Summary
Enhanced expression of tissue factor (TF) may result in thrombosis contributing to acute clinical consequences of coronary artery disease. Several studies demonstrated elevated plasma levels of TF in patients with acute coronary syndrome (ACS). The aim of our study was to compare the concentrations of TF in coronary sinus (CS), proximal part of the left coronary artery (LCA) and peripheral vein (PV) of patients with ACS and stable coronary artery disease (SCAD). Time course of the TF plasma levels in PV was followed on day 1 and day 7 after index event of ACS presentation and was compared to day 0 values. No heparin was given prior to the blood sampling. Twenty-nine patients in the ACS group (age 63.6 \pm 10.8 years, 20 males, 9 females) and 24 patients with SCAD (age 62.3 \pm 8.1 years, 21 males, 3 females) were examined. TF plasma level was significantly higher in patients with ACS than in those with SCAD $(239.0 \pm 99.3 \mathrm{ng} / \mathrm{ml}$ vs. $164.3 \pm 114.2 \mathrm{ng} / \mathrm{ml} ; \mathrm{p}=0.016)$. There was no difference in TF plasma levels in PV, CS and LCA (239.0 99.3 $\mathrm{ng} / \mathrm{ml}$ vs. $253.7 \pm 131.5 \mathrm{ng} / \mathrm{ml}$ vs. $250.6 \pm 116.4 \mathrm{ng} / \mathrm{ml}$, respectively). TF plasma levels tended to decrease only nonsignificantly on the day $7(224.4 \pm 109.8 \mathrm{ng} / \mathrm{ml})$. Significant linear correlation between TF and high sensitivity CRP (hs-CRP) levels on day 0 was found. In conclusion, TF plasma levels are elevated in patients with ACS not only locally in CS but also in systematic circulation. Our data support the relationship between TF production and proinflammatory mediators.
\end{abstract}

\section{Key words}

Coronary artery disease • Coronary thrombosis • Tissue factor

\section{Corresponding author}

Josef Bis, MD, First Department of Medicine, Charles University
Prague, Medical Faculty in Hradec Kralove, University Hospital Hradec Kralove, Sokolska 581, 50005 Hradec Kralove, Czech Republic. Fax: +420 495832 006. E-mail: bis@fnhk.cz

\section{Introduction}

Excessive expression of tissue factor (TF) may result in thrombosis contributing to acute clinical consequences of coronary artery disease. Several studies demonstrated elevated plasma levels of TF in patients with acute coronary syndrome (ACS) (Saigo et al. 2001, Kim et al. 2000, Seljeflot et al. 2003). The aim of our study was to compare the concentrations of $\mathrm{TF}$ in coronary sinus (CS), proximal part of the left coronary artery (LCA) and peripheral vein (PV) of patients with ACS and stable coronary artery disease (SCAD) and to assess its relations to the traditional biomarker of inflammation - hs-CRP levels (Nomoto et al. 2004).

\section{Patients and Methods}

Patients referred for coronary angiography were selected for the study and they were included into one of the two study groups. The first group comprised patients with STE and non-STE ACS. Patients with stable coronary artery disease (SCAD), mainly stable angina pectoris class II - III CCS were included into the second group. Subjects with cardiogenic shock, malignant arrhythmias and inflammatory diseases were excluded from the study.

Twenty-nine patients in the ACS group (age $63.6 \pm 10.8$ years, 20 males, 9 females) and 24 patients in 
the SCAD group (age 62.3 \pm 8.1 years, 21 males, 3 females) were examined. Characteristics of both groups are given in Table 1 . Informed consent was signed by all patients before the study. The study was approved by the local hospital Ethical Committee.

Table 1. Demographic data for the studied cohorts of patients.

\begin{tabular}{lcccc}
\hline & & ACS & & SCAD \\
& $\mathbf{n}$ & $\boldsymbol{0}$ & $\mathbf{n}$ & $\%$ \\
\hline$N$ & 29 & & 24 & \\
- males & 20 & 69 & 21 & 88 \\
- females & 9 & 31 & 3 & 12 \\
\hline
\end{tabular}

Age (years, mean $\pm S D)$

$63.6 \pm 10.8$

$62.3 \pm 8.1$

Risk factors

- positive family history

- $B M I>25$

$4 \quad 14$

$\begin{array}{lll}14 & 6 & 25\end{array}$

- arterial hypertension

$22 \quad 76$

22

18

- hyperlipoproteinemia

19

62

22

92

- diabetes mellitus

10

66

16

67

Insulin dependent

$10 \quad 34$

23

96

2

$34 \quad 10$

42

- smoking

2

7

2

8

$\begin{array}{ll}7 & 6\end{array}$

25

Previous history of $C A D$

10

34

13

54

Acute coronary syndrome

\begin{tabular}{lll} 
- STEMI & 13 & 45 \\
- NSTEMI/UAP & 16 & 55 \\
\hline
\end{tabular}

$\operatorname{LVEF}(\% \pm S D)$

$50.9 \pm 10.0$

$51.8 \pm 14.5$

Medical treatment:

$\begin{array}{lcccc}\text { - ASA } & 26 & 90 & 24 & 100 \\ - \text { - ASA }>7 D & 9 & 31 & 24 & 100 \\ \text { - thienopyridines } & 8 & 28 & 7 & 29 \\ \text { - } \beta \text {-blockers } & 21 & 72 & 24 & 100 \\ \text { - ACEI/ATII.bl. } & 11 & 38 & 20 & 83 \\ \text { - Ca-channel blockers } & 6 & 21 & 5 & 21 \\ \text { - diuretics } & 8 & 28 & 16 & 67 \\ \text { - statins } & 10 & 34 & 22 & 92 \\ - \text { - statins }>7 D & 11 & 38 & 21 & 88\end{array}$

ACS - patients with acute coronary syndrome. SCAD - patients with stable coronary artery disease. BMI=body mass index. CAD coronary artery disease. STEMI - acute myocardial infarction with ST segment elevations. NSTEMI - acute myocardial infarction without ST segment elevations. UAP - unstable angina pectoris. LV EF - left ventricular ejection fraction. ACEI - angiotensin converting enzyme inhibitors. ATII.bl - angiotensin II receptor blockers. ASA - acetylsalicylic acid. ASA > DD - chronic treatment of acetylsalicylic acid. Statins $>7 D$ - chronic statin treatment. 


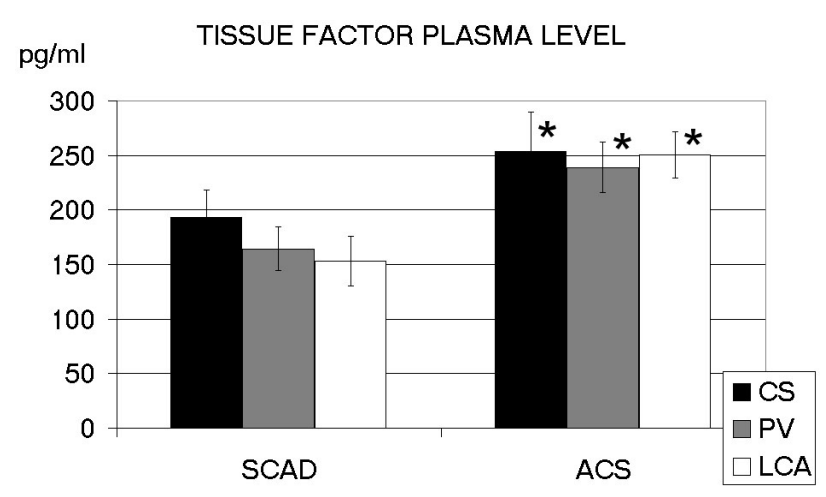

Fig 1. TF plasma levels in patients with ACS and SCAD in coronary sinus (CS), ostium of the left coronary artery (LCA) and peripheral vein $(\mathrm{PV}) . * \mathrm{p}<0.05$

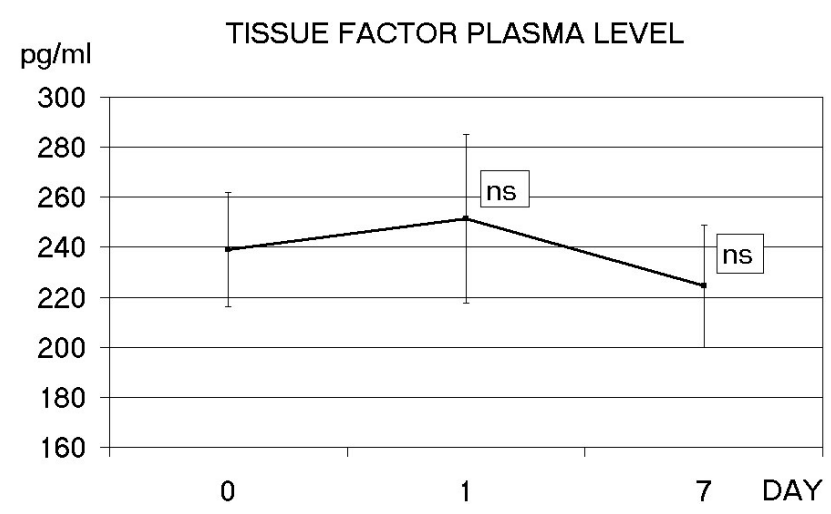

Fig 2. Time course of TF plasma levels in peripheral vein in patients in with ACS.

Tissue factor, tissue factor pathway inhibitor (TFPI) and high sensitivity C-reactive protein (hs-CRP) plasma levels were measured in the blood drawn from CS, LCA and PV of patients with ACS and SCAD. Time course of the TF, TFPI and hs-CRP peripheral blood plasma levels was followed on day 1 and day 7 after the first measurement and was compared to the day 0 values. Basic clinical data, resting ECG and biochemistry specimens were obtained in all patients.

Blood samples for TF, TFPI and hs-CRP measurements were drawn in fasting state (apart from several patients with an acute myocardial infarction) at the beginning of the heart catheterization. No heparin was given at least $24 \mathrm{~h}$ prior to the blood sampling. Mild sedation was introduced using $10 \mathrm{mg}$ of diazepam and $4 \mathrm{mg}$ of bisulepin. Amplatz right coronary catheter $5 \mathrm{~F}$ or $6 \mathrm{~F}$ (Cordis ${ }^{\circledR}$ ) was inserted under fluoroscopic control from right femoral vein into the coronary sinus and blood samples were withdrawn. Venous blood sampling from femoral vein was then carried out. Finally, left diagnostic $6 \mathrm{~F}$ Judkins coronary catheter was positioned into the ostium of the left coronary artery and blood samples were

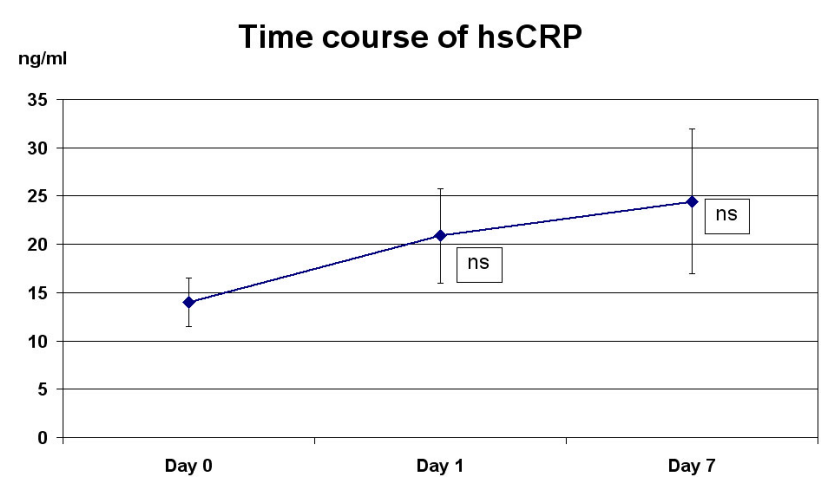

Fig 3. Individual values of TF plasma levels in patients with ACS on day 0,1 and 7.

\section{$\mathrm{TF} \mathbf{p g} / \mathrm{ml}$}

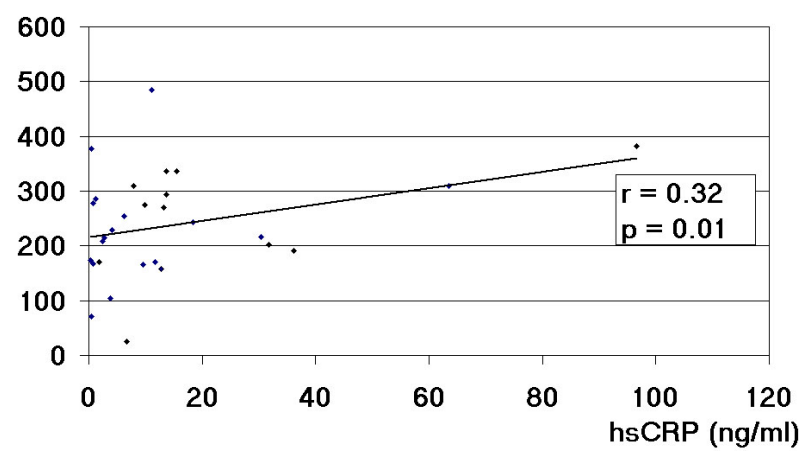

Fig 4. Correlation between hs-CRP and TF plasma levels.

obtained. Blood samples were placed into the ethylenediamine tetra-acetic acid (EDTA) tubes.

The plasma levels of TF, TFPI and hs-CRP were measured using commercially available kits.

\section{Tissue factor and tissue factor pathway inhibitor}

For TF and TFPI plasma level measurement, blood sample has been collected into $3.8 \%$ trisodium citrate solution in the proportion of 9 volumes of blood to 1 volume of anticoagulant solution. The sample has been centrifuged at $3.000 \mathrm{rpm}$ for $10 \mathrm{~min}$ and stored frozen until the measurement. The plasma has been thawed at $37{ }^{\circ} \mathrm{C}$ for $15 \mathrm{~min}$ before the final measurement.

Quantitation of TF was performed by ELISA, employing a murine anti-human TF monoclonal antibody for antigen capture (IMUBIND ${ }^{\circledR}$ Tissue Factor ELISA Kit, American Diagnostica, Inc.). TF levels were determined by measuring solution absorbances at $450 \mathrm{~nm}$ and comparing the values with those of standard curve.

Quantitation of TFPI was performed by „sandwich" ELISA employing a rabbit anti-human tissue factor pathway inhibitor polyclonal antibody (IMUBIND $^{\circledR}$ Total TFPI Elisa Kit, American Diagnostica, Inc.). TFPI was detected using a monoclonal 
antibody specific for Kunitz domain 1 of TFPI. TFPI levels were determined by measuring sample solution absorbance at $450 \mathrm{~nm}$ and comparing them against those of standard curve.

\section{High-sensitivity CRP}

High-sensitivity CRP was measured by chemiluminescent immunometric assay (DPC, USA). Samples were stored frozen at $-40{ }^{\circ} \mathrm{C}$. Repeated thawing and freezing of samples was avoided.

\section{Statistical analysis}

Statistical evaluation included the analysis of variance and Student's $t$ test for the assessment of differences of continuous variables. Correlations were analyzed using linear regression. $\mathrm{P}<0.05$ value was considered significant.

\section{Results}

TF plasma level was significantly higher in patients with ACS than in those with SCAD (239.0 099.3 $\mathrm{ng} / \mathrm{ml}$ vs. $164.3 \pm 114.2 \mathrm{ng} / \mathrm{ml} ; \mathrm{p}=0.016$ ). There was no difference in TF plasma levels in PV, CS and LCA $(239.0 \pm 99.3 \mathrm{ng} / \mathrm{ml}$ vs. $253.7 \pm 131.5 \mathrm{ng} / \mathrm{ml}$ vs $250.6 \pm 116.4$ $\mathrm{ng} / \mathrm{ml}$, respectively) (Fig. 1). TF plasma levels tended to decrease on the day $7(224.4 \pm 109.8 \mathrm{ng} / \mathrm{ml})$ (Figs 2 and 3). There were no differences between plasma TF levels neither in acute myocardial infarction nor in NAP. hs-CRP levels were also significantly higher in ACS group than in SCAD $(14.7 \pm 20.9 \mathrm{ng} / \mathrm{ml}$ vs. $3.99 \pm 7.05$ $\mathrm{ng} / \mathrm{ml} ; \mathrm{p}=0.013$ ) and tended to increase on day 1 $(20.9 \pm 26.6 \mathrm{ng} / \mathrm{ml})$ and day $7 \quad(24.4 \pm 42.7 \mathrm{ng} / \mathrm{ml})$. Significant linear correlation between TF and hs-CRP levels on day 0 was found (Fig. 4). There were no differences in TFPI plasma levels between patients with ACS and SCAD.

\section{Discussion}

Recent years have brought a gradual change in the understanding of the origin of acute coronary syndrome. The traditional interpretation of unstable forms of coronary disease as a cascade: unstable coronary plaque - unstable coronary artery - unstable patient, was proposed originally by Ambrose et al. (1986) and later generally accepted, resulted in an intensive search for a definite "culprit" lesion. It has been shown, however, that the stenosis responsible for an acute thrombotic occlusion of the artery need not always be the critical one, and that its histological characteristics are specific. Sophisticated methods have been developed with time to identify the plaques likely to cause an acute occlusion of coronary arteries. Yet, preventive sealing of such lesion by coronary angioplasty does not necessarily lead to the stabilization of the patient. Moreover, it has been documented that unstable coronary plaques are mostly multifocal (Nissen et al. 2001, Asakura et al. 2001, Goldstein et al. 2000, Rioufol et al. 2002) and that the inflammatory process in coronary circulation is widespread (Spagnoli et al. 2002, Buffon et al. 2002). The question therefore arises, whether the cellular and enzymatic interactions in the circulating blood - rather than local plaque rupture - are responsible for triggering the thrombotic process in the coronary circulation. TF is one of the key players in the initiation of thrombus formation in patients with acute coronary syndromes.

TF is a transmembrane lipoprotein responsible for the initiation of the coagulation cascade and it serves also as a signaling receptor. TF has a short cytoplasmatic and transmembrane domains and long extracellular domain. The latter forms with factor VII/VIIa a complex that directly converts factor $\mathrm{X}$ and also factor IX to their active forms. TF is expressed constitutively by monocytes, macrophages and fibroblasts. TF, however, may be expressed also in some other cell types in response to variety of stimuli. Thus smooth muscle cells have been shown to produce TF-positive microparticles after growth factor stimulation (Schecter et al. 1997). A binding of CD40 ligand also induced TF expression by smooth muscle cells in vitro (Schönbeck et al. 2000).

In normal arteries, TF expression is limited to the adventitia except for sporadic expression in the media (Wilcox et al. 1989). A small quantity of circulating TF is present in both whole blood and serum of healthy individuals (Giesen et al. 2000).

Apoptotic cells and microparticles in the atherosclerotic plaque have high procoagulant activity, which corresponds to the TF activity (Mallat et al. 1999). Moreover, activated cells shed fragments of their membrane into the extracellular space and these microparticles posses cytoplasmatic and cell membrane components with procoagulant activity due to the TF presence. Microparticle-bound TF originates from monocytes, polymorphonuclear cells, lymphocytes, platelets and endothelial and smooth muscle cells (Doshi et al. 2002). 
Recently, the importance of blood-borne TF has been shown. TF antigen and activity was found in the whole blood and plasma samples in different subsets of patients (Doshi et al. 2002). Neutrophils and monocytes were identified by immunostaining as the main source of circulating TF. Recent data also indicate that circulating TF may be more important for initiation and propagation of the thrombus formation than TF originating from the vessel wall. Platelet-derived microvesicles are the prevalent location of the plasma TF. This was confirmed by the presence of full-length TF in the microvesicles acutely shedded from activated platelets. Blood TF activity is thus dependent on the microvesicle and activated platelet TF and enables the entire coagulation system to proceed on a restricted cell surface (Müller et al. 2003). These platelet-derived microvesicles possibly transfer platelet-released TF to monocytes (Scholz et al. 2002). Chou et al. (2004) and Niemetz (2005) showed that blood-borne TF associated with hematopoietic cellderived microparticles contributes considerably to the thrombus formation.

Excessive expression of TF may initiate the thrombotic process contributing to acute clinical consequences of coronary artery disease. Experimental data show that atheromatous plaques contain a high concentration of TF relative to surrounding tissue (Marmur et al. 1996). Abundant TF was also found in atheromatous lesions within foamy macrophages in macrovascular disease of the aorta and carotid arteries (Wilcox et al. 1989). Modified ELISA (Westmuckett et al. 2000) and a rabbit polyclonal antibody against the solubilized TF antigen (Thiruvikraman et al. 1996) were used for in situ localization of $\mathrm{TF}$ in human atherosclerotic plaques. Quantitation of TF antigen was done to test the hypothesis that thrombin generation takes place directly in the atherosclerotic lesion (Thiruvikraman et al. 1996).

Several studies demonstrated elevated $\mathrm{TF}$ plasma levels in patients with myocardial infarction (Saigo et al. 2001, Seljeflot et al. 2003), stable angina (Kim et al. 2000), unstable angina as well as an increased risk for unfavorable outcomes in patients with unstable angina and raised TF levels (Soejima et al. 1999). Other authors found only an insignificant trend to raised plasma levels of TF in patients with acute myocardial infarction and unstable angina pectoris as compared to patients with stable coronary artery disease and normal subjects (Malý et al. 2003). TF could be useful for the evaluation of the effect of cardiovascular risk intervention, but results in this field are still controversial (Lim et al. 2004). Some authors (Lim et al. 2004, Sambola et al. 2003) reported higher plasma levels of TF in patients with diabetes than in control subjects. They suggest that higher levels of TF may be the mechanism responsible for the increased thrombotic complications associated with the presence of other cardiovascular risk factors. No significant differences were found between diabetics and non-diabetics in patients with chronic renal failure (Zemanová et al. 2003). High levels of serum TF were not independently associated with an increased risk of future coronary artery disease in healthy individuals (Keller et al. 2006).

In our study, TF plasma level was significantly elevated in patients with ACS and this elevation persisted for at least 7 days after acute clinical presentation. Moreover, we did not find any differences between the local TF antigen plasma levels in the coronary circulation and in the peripheral vein. These findings would support the notion that blood-born TF may be clinically important for the development of ACS in the predisposed patients. Our data also corroborated the relationship between TF production and proinflammatory mediators.

The plasma level of TF may be determined by means of several commercially available ELISA kits, one-stage clotting or chromogenic assays or quantitative immunostaining technique (In-Cell Western). In our series the IMUBIND ${ }^{\circledR}$ Tissue Factor ELISA Kit (American Diagnostica, Inc.) has been used. The kit employs a murine anti-human TF monoclonal antibody for antigen capture. However, this technique also measures degraded TF with epitopes recognized by antibodies but biologically inactive. Alternatively, plasma TF activity as TF-dependent generation of factor Xa can be used to assess the functional activity of $\mathrm{TF}$ (Westmuckett et al. 2000, Thiruvikraman et al. 1996).

The limitation of our study as well as most previously reported clinical series is that TF antigen was measured, and this may not precisely reflect the true biological activity of tissue factor. Increased plasma TF activity and antigen level may be regarded as a marker of early stage of TF-induced coagulation and its measurement may provide some information on potential trigger of the clotting in different clinical settings. Routine assessment of TF in patients with coronary artery disease is, however, limited by the cost, low specificity and lack of long-term clinical data. The decision-making in patients with acute coronary syndrome in the present time is still based on the 
traditional biomarkers (e.g. markers of myocardial necrosis - troponins, markers of inflammation - hsCRP). Nevertheless, TF activity assessment may be helpful in the future for possible clinical application of the inhibition of the earliest stages of the coagulation cascade - the TF/FVIIa pathway (Eilertsen et al. 2004).

\section{Conflict of Interest}

There is no conflict of interest.

\section{Acknowledgements}

This paper was supported by research grant NR/9176-3 (Internal Grant Agency, Ministry of Health CR).

\section{References}

AMBROSE JA, WINTERS SL, ARORA RR, ENG A, RICCIO A, GORLIN R: Angiographic evaluation of coronary artery morphology in unstable angina. $J$ Am Coll Cardiol 7: 472-478, 1986.

ASAKURA M, UEDA Y, YAMAGUCHI O, ADACHI T, HIRAYAMA A, HORI M, KODAMA K: Extensive development of vulnerable plaques as a pan-coronary process in patients with myocardial infarction: an angioscopic study. J Am Coll Cardiol 37: 1284-1288, 2001.

BUFFON A, BIASUCCI LM, LIUZZO G, D'ONOFRIO G, CREA F, MASERI A: Widespread coronary inflammation in unstable angina. $N$ Engl J Med 347: 5-12, 2002.

CHOU J, MACKMAN N, MERRILL-SKOLOFF G, PEDERSEN B, FURIE BC, FURIE B: Hematopoietic cell-derived microparticle tissue factor contributes to fibrin formation during thrombus propagation. Blood 104: 3190-3197, 2004.

DOSHI SN, MARMUR JD: Evolving role of tissue factor and its pathway inhibitor. Crit Care Med 30 (Suppl): S241S250, 2002.

EILERTSEN KE, ØSTERUD B: Tissue factor: (patho)physiology and cellular biology. Blood Coagul Fibrinolysis 15: 521-538, 2004.

GIESEN PL, NEMERSON Y: Tissue factor on the loose. Semin Thromb Hemost 26: 379-384, 2000.

GOLDSTEIN JA, DEMETRIOU D, GRINES C, PICA M, SHOUKFEH M, O'NEILL WW: Multiple complex coronary plaques in patients with acute myocardial infarction. $N$ Engl J Med 343: 915-922, 2000.

KELLER TT, CHOI D, NAGEL C, TE VELTHUIS H, GERDES VE, WAREHAM NJ, BINGHAM SA, LUBEN R, HACK CE, REITSMA PH, LEVI M, KHAW KT, BOEKHOLDT SM: Tissue factor serum levels and the risk of future coronary artery disease in apparently healthy men and women: the EPIC-Norfolk prospective population study. J Thromb Haemost 4: 2391-2396, 2006.

KIM HK, SONG KS, PARK YS, YUN YS, SHIM WH: Changes of plasma tissue factor and tissue factor pathway inhibitor antigen levels and induction of tissue factor expression on the monocytes in coronary artery disease. Cardiology 93: 31-36, 2000.

LIM HS, BLANN AD, LIP GY: Soluble CD40 ligand, soluble P-selektin, interleukin-6, and tissue factor in diabetes mellitus. Circulation 109: 2524-2528, 2004.

MALLAT Z, HUGEL B, OHAN J, LESECHE G, FREYSSINET JM, TEDGUI A: Shed membrane microparticles with procoagulant potential in human atherosclerotic plaques: a role for apoptosis in plaque thrombogenicity. Circulation 99: 348-353, 1999.

MALÝ M, VOJÁČEK J, HRABOŠ V, KVASNIČKA J, SALAJ P, DURDIL V: Tissue factor, tissue factor pathway inhibitor and cytoadhesive molecules in patients with an acute coronary syndrome. Physiol Res 52: 719-728, 2003.

MARMUR JD, THIRUVIKRAMAN SV, FYFE BS, GUHA A, SHARMA SK, AMBROSE JA, FALLON JT, NEMERSON Y, TAUBMAN MB: Identification of active tissue factor in human atherosclerotic plaques in human coronary atheroma. Circulation 94: 1226-1232, 1996.

MÜLLER I, KLOCKE A, ALEX M, KOTZSCH M, LUTHER T, MORGENSTERN E, ZIESENISS S, ZAHLER S, PREISSNER K, ENGELMANN B: Intravascular tissue factor initiates coagulation via circulating microvesicles and platelets. FASEB J 17: 476-478, 2003.

NIEMETZ J: Tissue-factor-endowed leukocytes do cause thrombosis. Blood 106: 1506, 2005. 
NISSEN SE, YOCK P: Intravascular ultrasound. Novel pathophysiological insights and current clinical applications. Circulation 103: 604-616, 2001.

NOMOTO K, OGUCHI S, WATANABE I, KUSHIRO T, KANMATSUSE K: Involvement of inflammation in acute coronary syndromes assessed by levels of high-sensitivity C-reactive protein, matrix metalloproteinase- 9 and soluble vascular-cell adhesion molecule-1. J Cardiol 42: 201-206, 2003.

RIOUFOL G, FINET G, GINON I, ANDRÉ-FOUËT X, ROSSI R, VIALLE E, DESJOYAUX E, CONVERT G, HURET JF, TABIB A: Multiple atherosclerotic plaque rupture in acute coronary syndrome. A three-vessel intravascular ultrasound study. Circulation 106: 804-808, 2002.

SAIGO M, ABE S, OGAWA M, YAMASHITA T, BIRO S, MINAGOE S, MARUYAMA I, TEI C: Imbalance of plasminogen activator inhibitor-I/tissue plasminogen activator and tissue factor/tissue factor pathway inhibitor in young Japanese men with myocardial infarction. Thromb Haemost 85: 1197-1203, 2001.

SAMBOLA A, OSENDE J, HATHCOCK J, DEGEN M, NEMERSON Y, FUSTER V, CRANDALL J, BADIMON JJ: Role of risk factors in the modulation of tissue factor activity and blood thrombogenicity. Circulation 107: 973-977, 2003.

SCHECTER AD, GIESEN PL, TABY O, ROSENFIELD CL, ROSSIKHINA M, FYFE BS, KOHTZ DS, FALLON JT, NEMERSON Y, TAUBMAN MB: Tissue factor expression in human arterial smooth muscle cells: TF is present in three cellular pools after growth factor stimulation. J Clin Invest 100: 2276-2285, 1997.

SCHOLZ T, TEMMLER U, KRAUSE S, HEPTINSTALL S, LOSCHE W: Transfer of tissue factor from platelets to monocytes: role of platelet-derived microvesicles and CD62P. Thromb Haemost 88: 1033-1038, 2002.

SCHÖNBECK U, MACH F, SUKHOVA GK, HERMAN M, GRABER P, KEHRY MR, LIBBY P: CD40 ligation induces tissue factor expression in human vascular smooth muscle cells. Am J Pathol 156: 7-14, 2000.

SELJEFLOT I, HURLEN M, ARNESEN H: Levels of soluble tissue factor related to future clinical events in patients with myocardial infarction. Thromb Haemost (Suppl 1): abstract P0495, 2003.

SOEJIMA H, OGAWA H, YASUE H, KAIKITA K, NISHIYAMA K, MISUMI K, TAKAZOE K, MIYAO Y, YOSHIMURA M, KUGIYAMA K, NAKAMURA S, TSUJI I, KUMEDA K: Heightened tissue factor associated with tissue factor pathway inhibitor and prognosis in patients with unstable angina. Circulation 99: 2908-2913, 1999.

SPAGNOLI LG, BONANNO E, MAURIELlO A, PALMIERI G, PARTENZI A, SANGIORGI G, CREA F: Multicentric inflammation in epicardial coronary arteries of patients dying of acute myocardial infarction. $J \mathrm{Am}$ Coll Cardiol 40: 1579-1588, 2002.

THIRUVIKRAMAN SV, GUHA A, ROBOZ J, TAUBMAN MB, NEMERSON Y, FALLON JT: In situ localization of tissue factor in human atherosclerotic plaques by binding of digoxigenin-labeled factors VIIa and X. Lab Invest 75: 451-461, 1996.

WESTMUCKETT AD, LUPU C, GOULDING DA, DAS S, KAKKAR VV, LUPU F: In situ analysis of tissue factordependent thrombin generation in human atherosclerotic vessels. Thromb Haemost 84: 904-911, 2000.

WILCOX JN, SMITH KM, SCHWARTZ SM, GORDON D: Localization of tissue factor in the normal vessel wall and the atherosclerotic plaque. Proc Natl Acad Sci USA 86: 2839-2843, 1989.

ZEMANOVÁ P, OPATRNÝ K, OPATRNÁ S, VÍT L, ŠEFRNA F, RACEK J: Tissue factor, its pathway inhibitor, and metabolic disturbances in long-term peritoneal dialysis. Kidney Blood Press Res 26: 368-375, 2003. 